collection of bronze age pottery from Cyprus, which had been excavated by Mr. J. R. Stewart from two graves at Vounous in that island. The pottery belongs to the periods Early Cypriote Ia and $\mathrm{I} b$, dating from about 2800-2700 B.C., and Early Cypriote II $a$, which is placed at approximately two hundred years later. Lieut.-Colonel H. H. R. Deane has presented a collection of examples of Buddhist art, consisting of twenty pieces, mostly small stone figures, belonging to the Gandhara School, dating from the second to fourth centuries A.D. These were collected in the North-West Frontier Province by the late Lieut.-Colonel H. A. Deane.

\section{Recent Appointments in the Colonial Service}

THE following appointments in the Colonial Service have recently been made: Colonial Forest Service, W. B. Collins, Gold Coast ; D. F. Davidson, Cyprus ; M. T. Horwood, Gold Coast ; F. C. Hummel, Uganda; T. W. Hussey, Nigeria; D. M. M. Kellas, Gold Coast ; D. A. Lane, Gold Coast ; H. M. MaughanBrown, Sierra Leone; W. A. Miller, Gold Coast ; J. M. Ramsay, Gold Coast ; G. G. K. Setton, Fiji ; P. G. Shillitoe, Tanganyika. Colonial Agricultural Service, C. Harvey (agricultural officer, Tanganyika Territory), senior agrieultural officer, Fiji; F. L. Squibbs (director of agriculture, Seychelles), agricultural officer, Gold Coast. Colonial Geological Survey Service, J. B. Alexander (geologist, Nyasaland), geologist, Federated Malay States ; H. Service (geologist, Gold Coast), geologist, Federated Malay States. Colonial Veterinary Service, W. G. Beaton (senior veterinary officer), deputy director of veterinary services, Nigeria; H. J. Lowe (senior veterinary officer), director of veterinary services, Tanganyika Territory; Captain W. L. S. Mackintosh (veterinary officer), senior veterinary officer, Uganda ; R. J. Simmons (senior veterinary officer), director of veterinary services, Uganda. Other Branches, W. R. Chanmugam (assistant Government analyst), deputy Government analyst, Ceylon; Miss R. M. Henderson, bacteriologist, Veterinary Department, Kenya; G. P. C. Lewis, inspector of plants and produce, Gold Coast.

\section{Announcements}

M. L. Cayeux, member of the Paris Academy of Sciences and honorary professor of geology at the Collège de France, has been awarded the Paul Fourmarier Prize and gold medal by the Royal Academy of Belgium.

THE Council of the Institution of Naval Architects has awarded the Gold Medal of the Institution for the year 1938 to A. P. Cole, for his paper "Destroyer Turning Circles", and the Premium to Dr. F. H. Todd and J. Weedon for their joint paper "Further Resistance and Propeller Experiments with Models of Coasters". The Wakeham Prize for 1938 has been awarded to I. C. Bridge for his paper "Structural Stress in an Oil Tanker Under Service Conditions". These awards will be presented at the annual general meeting on March 29 at the Royal Society of Arts, John Street, London, W.C.2.
The Gold Medal of the Intermational Faculty of Sciences, which is awarded annually in recognition of outstanding contributions to scientific progress, has been awarded for 1938 to Mr. J. J. Denton, secretary of the Television Society, and vice-president of the Institution of Electronics. The award is in recognition of nearly fifty years' continuous devotion to scientific and technical education.

THE herbarium and library of the Botanical Museum of the Academy of Sciences of the U.S.S.R. are being transferred from Leningrad to Moscow. It is not expected that the new museum in Moscow will be ready for another five years. The Botanical Gardens in Leningrad will be retained.

WE have received a new schedule of fees for tests on volumetric glassware at the National Physical Laboratory which came into operation on December 1, certain modifications in the method of charging being introduced. The tests available and the methods used are described in a pamphlet entitled "Tests on Volumetric Glassware" which, together with the schedule of fees, may be obtained on application to the Director, National Physical Laboratory, Teddington, Middlesex.

The Educational Advisory Board of the British Social Hygiene Council is holding a Summer School, dealing with "Biology in Human Life", probably at Cambridge, on July 28-August 4. The School will include courses on social biology, and the place of the teacher with regard to the teaching of sex, and lectures by experts on recent developments in the biological field. The course is intended for all teachers, particularly those in senior and secondary schools, who are interested in biological problems as they affect human life and society. Further particulars can be obtained from the Education Officer, British Social Hygiene Council, Tavistock House South, Tavistock Square, London, W.C.1.

The fourth biennial Child Guidance Conference will be held at the British Medical Association House, Tavistock Square, W.C.1, on January 27-28, when the subjects for discussion will include : treatment of parents, juvenile delinquency, personality deviations and diagnosis of psychoses, the scope of the educational psychologist working in the schools and substitute homes. A session for administrative regulations will also be devoted to the consideration of the findings of the Feversham report on the voluntary mental health services as they affect the policy and administration of the child guidance movement. Further information can be obtained from the Secretary, Child Guidance Council, Woburn House, Upper Woburn Place, W.C.1.

ErRatum.-In Nature of December 3, 1938, p. 997, col. 2, letter by Prof. A. Schönberg, last reaction :

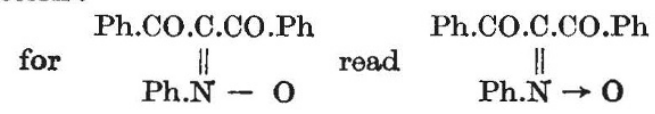

